\title{
GENE EFFECT, COMBINING ABILITY AND HETEROSIS IN SUNFLOWER MORPHOPHYSIOLOGICAL TRAITS
}

\author{
Hladni, N. ${ }^{1^{*}}$, Terzić, S. ${ }^{1}$, Miklič, V. ${ }^{1}$, Jocić, S. ${ }^{2}$, \\ Kraljević-Balalić, M. ${ }^{3}$, Škorić, D. ${ }^{3}$
}

${ }^{1}$ Institute of Field and Vegetable Crops, 21000 Novi Sad, Serbia
${ }^{2}$ Faculty of Agriculture, 21000 Novi Sad, Serbia
${ }^{3}$ Serbian Academy of Science and Arts, Branch in Novi Sad, Serbia

Received: November 15, 2011 Accepted: December 10, 2011

\section{SUMMARY}

Four interspecies populations, originating from three annual $(H$. debilis, H. praecox, H. deserticola) and one perennial (H. resinosus) wild species, were used to produce 13 new ( $\mathrm{cms}$ ) inbred lines with cytoplasmic male sterility, three $R f$ restorer lines with good general combining ability used as testers and their $\mathrm{F}_{1}$ hybrids. A two-year trial with three replicates was set up using the line $\times$ tester method. The inbred A-lines, $R f$-testers and $\mathrm{F}_{1}$ hybrids differed significantly in the mean values for both studied traits. The mode of inheritance for leaf area was dominance and superdominance of the better parent and for plant height it was superdominance of the better parent. Highly significant positive values of general combining ability for both traits were found in inbred lines NS-G-7, NS-G-8, NS-G-9. The greatest highly significant positive specific combining ability value was found in NS-G- $6 \times$ RUS-Rf-OL- 168 for the total leaf area per plant and in NS-G-6 $\times$ RHA-N-49 for plant height. The non-additive gene effect had greater influence on both traits. A significant heterotic effect was found for both traits in relation to the parental average so as in relation to the better parent.

Key words: sunflower, mode of inheritance, combining abilities, components of genetic variance, heterosis

\section{INTRODUCTION}

One of the main directions of sunflower breeding both in Serbia and in other locations is the development of hybrids with a high genetic potential for seed yield and altered plant architecture capable of adapting to the conditions of the specific area in which they are grown (Hladni et al., 2008a). The ideal sunflower plant model does not exist. So in order to increase the number of plants per area unit, when creating new sunflower hybrids, it is necessary to pay attention to the architecture of those plant organs that have great effect on the plant and a direct influ- 
ence on the formation of seed yield per area unit. Sunflower breeding for the desirable plant architecture and direct components of seed yield demands the creation of divergent material in the breeding programme. The genus Helianthus, apart from constituting the basic genetic stock, which cultivated sunflower originated from, continues to contribute to specific characteristics for cultivated sunflower improvement (Seiler, 2010). Breeding for yield components and the creation of a new sunflower ideotype require an increased use of wild Helianthus species in breeding programs (Hladni et al., 2011). One of safe ways of increasing the genetic variability of the genus Helianthus is the discovery of desirable genes in the wild species and their incorporation into cultivated sunflower genotypes by interspecies hybridization (Škorić et al., 2007; Hladni et al., 2009). In sunflower breeding we come across a large number of different genotypes regarding morphophysiological traits. When a breeding program begins, the choice of parents is very important for both short and long term breeding (Hladni et al., 2010a).

The basic leaf function is photosynthesis. In the process of photosynthesis 90$95 \%$ of the organic material is created. Number of leaves and their size determine the total leaf or assimilation area. Sakač et al. (1997) stated that moderate size of leaf area and leaf area duration are important factors of high seed and oil yield. Total leaf area (TLA) depends on the position of the leaf, leaf area profile, plant development, and genotype (Panković et al., 1991). During the flowering stage, the biggest part of the sunflower leaf area is formed, this influences the high transpiration and photosynthesis intensity. Leaf area and photosynthesis intensity in each stage of development are increased from the basis to the maximal value which is gained at 85\% maximal plant height. According to Kovačik and Škaloud (1990) and Hladni et al. (2003) the biggest importance in the inheritance of total leaf area is given to the non-additive component of the genetic variance and the mode of inheritance of the leaf area was dominance of the better parent, as well as superdominance.

Plant height plays a major role in the creation of new SC-hybrids with a different plant model and high genetic potential for seed and oil yield. Plant height is a very important trait because it depends on the stability of the plant i.e., the resistance to lodging (Hladni, 2010).

Hladni et al. (2004) determined that the mode of inheritance of plant height in the $\mathrm{F}_{1}$ and $\mathrm{F}_{2}$ generation was superdominance, also partial dominance of the parent with a higher mean value and dominance of the parent with a higher mean value appeared. By crossing the cultivated with the wild sunflower forms partial dominance and dominance of the wild species were noticed in the inheritance of the plant height as stated by Terzić et al. (2006). Role of additive genes in total leaf area inheritance was reported by Naik et al. (1999).

The predominant role in the inheritance of the plant height was held by the additive component of the genetic variance Shekar et al. (2000), Marinković (2005), 
while Škorić et al. (2000), Burli et al. (2001), Goksoy et al. (2004) determined a higher ratio of the non-additive gene effect.

Significant manifestation of heterosis for agronomically important traits is the main precondition for obtaining productive sunflower hybrids (Škorić et al., 2006).

The occurrence of heterosis in sunflower hybrids is highly connected to a genetic distance between the parental lines. Heterosis does not appear in all hybrid combinations of the $F_{1}$ generation. Heterotic effects are different for different traits. Both total leaf area per plant and plant height have great importance in the creation of new SC-hybrids with changed plant model and a high genetic potential for seed and oil yield.

The objective of this study was to investigate general combining ability (GCA) effects in new divergent inbred lines obtained by interspecies hybridization, specific combining ability (SCA) effects of the $F_{1}$ hybrids, gene effects, components of genetic variance, average percentage contributions of the lines, testers and their interactions with the expression of the studied morphophysiological traits and to monitor the occurrence of heterosis for total leaf area per plant (TLA) and plant height $(\mathrm{PH})$.

\section{MATERIAL AND METHOD}

13 new divergent (A) cms inbred lines, $3 R f$-restorer lines, $39 \mathrm{~F}_{1}$ hybrids developed at the Institute of Field and Vegetable Crops in Novi Sad were used in this research. Four interspecies populations, originating from three annual (H. debilis, $H$. praecox runyoli, $H$. deserticola) and one perennial (H. resinosus) wild species, were used to produce 13 new $\mathrm{cms}$ inbred lines (NS-G-1, NS-G-2, NS-G-3, NS-G-4, NS-G-5, NS-G-6, NS-G-7, NS-G-8, NS-G-9, NS-G-10, NS-G-11, NS-G-12, NS-G13). Restorer male inbred (RHA-R-PL-2/1, RHA-N-49, RUS-RF-OL-168) with good combining abilities were used as testers in the form of fertility restorers. The $\mathrm{F}_{1}$ hybrids had been developed by crossing each tester with each female inbred line. The trial was carried out at the Institute's experiment field at Rimski Šančevi. There were three replications, and the experiment was designed according to the line $\times$ tester method. The lines and hybrids were planted manually at an optimum time during the middle of April on a well-prepared soil. The plots consisted of four rows with 12 plants in each. The row-to-row spacing was $70 \mathrm{~cm}$ and the plants were spaced at $30 \mathrm{~cm}$ intervals within the rows. Each trait was analyzed on a sample consisting of 30 plants ( 10 per replicate) taken from the middle rows in each block. Total leaf area per plant (TLA) $\left(\mathrm{cm}^{2}\right)$ was measured by a leaf area meter (LI-300LiCOR, USA) at the flowering stage while the plant height $(\mathrm{cm})$ was measured in the field at the stage of physiological maturity. For the evaluation of the test of significance ( $t$-test), the middle values of hybrids in relation to the parental average (Kraljević-Balalić et al., 1991) were used. The mean values of the inbred lines and $\mathrm{F}_{1}$ hybrids were used to calculate the values of the combining abilities and assess the gene effects for morphophysiological traits using the line $\times$ tester method (Singh and Choudhary, 1976). Heterosis was being calculated in relation to the 
mean parental value $\left(\mathrm{H}_{1}\right)$ or to the mean value of the better parent $\left(\mathrm{H}_{2}\right)$. Heterosis was assessed according to Jinks (1983).

\section{RESULTS AND DISCUSSION}

Yield or productivity is an economically metric trait that is of the greatest significance for breeders. The development of sunflower hybrids with high genetic potentials for seed yield requires information about the mode of inheritance, general combining ability (GCA) and specific combining ability (SCA) for seed yield and important morphophysiological traits in the $\mathrm{F}_{1}$ generation.

The significant differences in TLA and PH between the A lines and Rf testers on one side and their $F_{1}$ hybrids on the other indicate the presence of genetic differences among the studied genotypes. Of the A-lines, NS-G-13 had the smallest $\left(0.456 \mathrm{~m}^{2}\right)$ and NS-G-3 the greatest TLA $\left(680 \mathrm{~m}^{2}\right)$, while in the Rf-testers RHA-R-Pl$2 / 1$ was the smallest $\left(0.603 \mathrm{~m}^{2}\right)$ and RUS-RF-OL-168 the greatest $\left(0.802 \mathrm{~m}^{2}\right)$. Among the $\mathrm{F}_{1}$ hybrids, NS-G-5 $\times$ RUS-RF-OL-168 had the smallest $\left(0.607 \mathrm{~m}^{2}\right)$ and NS-G-7 $\times$ RUS-RF-OL-168 the greatest average TLA $\left(1.146 \mathrm{~m}^{2}\right)$. Of the A-lines, NSG-13 had the smallest $(73.1 \mathrm{~cm})$ and NS-G-4 the greatest PH $(116.4 \mathrm{~cm})$, while in the $R f$-testers RHA-N-49 was the shortest $(99.5 \mathrm{~cm})$ and RUS-RF-OL-168 the tallest $(116.1 \mathrm{~cm})$. Among the $\mathrm{F}_{1}$ hybrids, NS-G-10 $\times$ RUS-RF-OL-168 had the smallest $(129.8 \mathrm{~cm})$ and NS-G-9 $\times$ RHA-N-49 the greatest average PH $(168.3 \mathrm{~cm})$, Table 1.

Table 1: Mean values and mode of inheritance of total leaf area per plant (TLA) and plant height $(\mathrm{PH})$

\begin{tabular}{llcc}
\hline & \multicolumn{1}{c}{ Parents and hybrids } & TLA & PH \\
& & $\mathrm{m}^{2}$ & $\mathrm{~cm}$ \\
\hline 1 & NS-G-1 RES & 0,555 & 93,5 \\
2 & NS-G-2 RES & 0,656 & 99,0 \\
3 & NS-G-3 RES & 0,680 & 104,4 \\
4 & NS-G-4 DEB-SIL & 0,672 & 116,4 \\
5 & NS-G-5 DEB-SIL & 0,649 & 114,2 \\
6 & NS-G-6 DEB-SIL & 0,636 & 109,8 \\
7 & NS-G-7 PRA-RUN & 0,486 & 111,9 \\
8 & NS-G-8 PRA-RUN & 0,529 & 93,0 \\
9 & NS-G-9 PRA-RUN & 0,636 & 92,7 \\
10 & NS-G-10 DES & 0,514 & 79,3 \\
11 & NS-G-11 DES & 0,592 & 89,6 \\
12 & NS-G-12 DES & 0,618 & 90,1 \\
13 & NS-G-13 DES & 0,456 & 73,1 \\
14 & RHA-R-PL-2/1 & 0,603 & 116,1 \\
15 & RHA-N-49 & 0,705 & 99,5 \\
16 & RUS-RF-OL-168 & 0,802 & 114,0 \\
17 & $1 \times 14 \quad$ NS-G-1 $\times$ RHA-R-PL-2/1 & $0,938^{\mathrm{h}}$ & $139,6^{\mathrm{h}}$ \\
18 & $1 \times 15 \quad$ NS-G-1 $\times$ RHA-N-49 & $0,760^{\mathrm{d}}$ & $150,8^{\mathrm{h}}$ \\
\hline
\end{tabular}


Table 1: Mean values and mode of inheritance of total leaf area per plant (TLA) and plant height $(\mathrm{PH})$

\begin{tabular}{|c|c|c|c|c|}
\hline 19 & $1 \times 16$ & NS-G-1 $\times$ RUS-RF-OL-168 & $0,794^{\mathrm{pd}+}$ & $130,7^{h}$ \\
\hline 20 & $2 \times 14$ & NS-G-2 $\times$ RHA-R-PL-2/1 & $0,875^{\mathrm{h}}$ & $143,3^{h}$ \\
\hline 21 & $2 \times 15$ & NS-G-2 $\times$ RHA-N-49 & $0,804^{\mathrm{h}}$ & $152,2^{h}$ \\
\hline 22 & $2 \times 16$ & NS-G-2 × RUS-RF-OL-168 & $0,768^{\mathrm{i}}$ & $138,7^{\mathrm{h}}$ \\
\hline 23 & $3 \times 14$ & NS-G-3 $\times$ RHA-R-PL-2/1 & $0,768^{\mathrm{h}}$ & $143,2^{h}$ \\
\hline 24 & $3 \times 15$ & NS-G-3 $\times$ RHA-N-49 & $0,697^{i}$ & $149,2^{h}$ \\
\hline 25 & $3 \times 16$ & NS-G-3 × RUS-RF-OL-168 & $0,852^{d}$ & $138,4^{\mathrm{h}}$ \\
\hline 26 & $4 \times 14$ & NS-G-4 × RHA-R-PL-2/1 & $0,900^{\mathrm{h}}$ & $158,4^{\mathrm{h}}$ \\
\hline 27 & $4 \times 15$ & NS-G-4 × RHA-N-49 & $0,868^{h}$ & $164,9^{h}$ \\
\hline 28 & $4 \times 16$ & NS-G-4 × RUS-RF-OL-168 & $0,761^{i}$ & $152,3^{\mathrm{h}}$ \\
\hline 29 & $5 \times 14$ & NS-G-5 $\times$ RHA-R-PL-2/1 & $0,732^{h}$ & $160,3^{h}$ \\
\hline 30 & $5 \times 15$ & NS-G-5 $\times$ RHA-N-49 & $0,728^{d}$ & $161,2^{\mathrm{h}}$ \\
\hline 31 & $5 \times 16$ & NS-G-5 × RUS-RF-OL-168 & $0,607^{\mathrm{d}-}$ & $158,5^{h}$ \\
\hline 32 & $6 \times 14$ & NS-G-6 $\times$ RHA-R-PL-2/1 & $0,741^{\mathrm{h}}$ & $151,4^{\mathrm{h}}$ \\
\hline 33 & $6 \times 15$ & NS-G- $6 \times$ RHA-N-49 & $0,708^{d}$ & $157,5^{\mathrm{h}}$ \\
\hline 34 & $6 \times 16$ & NS-G-6 $\times$ RUS-RF-OL-168 & $0,956^{h}$ & $142,2^{\mathrm{h}}$ \\
\hline 35 & $7 \times 14$ & NS-G-7 $\times$ RHA-R-PL-2/1 & $1,025^{h}$ & $167,3^{h}$ \\
\hline 36 & $7 \times 15$ & NS-G-7 $\times$ RHA-N-49 & $0,957^{\mathrm{h}}$ & $159,4^{\mathrm{h}}$ \\
\hline 37 & $7 \times 16$ & NS-G-7 × RUS-RF-OL-168 & $1,146^{\mathrm{h}}$ & $161,0^{h}$ \\
\hline 38 & $8 \times 14$ & NS-G-8 $\times$ RHA-R-PL-2/1 & $1,057^{\mathrm{h}}$ & $159,8^{\mathrm{h}}$ \\
\hline 39 & $8 \times 15$ & NS-G- $8 \times$ RHA-N-49 & $1,002^{h}$ & $159,9^{h}$ \\
\hline 40 & $8 \times 16$ & NS-G-8 × RUS-RF-OL-168 & $0,986^{\mathrm{h}}$ & $155,5^{\mathrm{h}}$ \\
\hline 41 & $9 \times 14$ & NS-G-9 $\times$ RHA-R-PL-2/1 & $0,835^{\mathrm{h}}$ & $167,5^{\mathrm{h}}$ \\
\hline 42 & $9 \times 15$ & NS-G- $9 \times$ RHA-N-49 & $0,835^{\mathrm{h}}$ & $168,3^{h}$ \\
\hline 43 & $9 \times 16$ & NS-G-9 × RUS-RF-OL-168 & $0,898^{\mathrm{h}}$ & $159,4^{\mathrm{h}}$ \\
\hline 44 & $10 \times 14$ & NS-G-10 $\times$ RHA-R-PL-2/1 & $0,797^{\mathrm{h}}$ & $136,0^{\mathrm{h}}$ \\
\hline 45 & $10 \times 15$ & NS-G-10 $\times$ RHA-N-49 & $0,778^{d}$ & $144,6^{\mathrm{h}}$ \\
\hline 46 & $10 \times 16$ & NS-G-10 $\times$ RUS-RF-OL-168 & $0,708^{i}$ & $129,8^{\mathrm{h}}$ \\
\hline 47 & $11 \times 14$ & NS-G-11 $\times$ RHA-R-PL-2/1 & $0,705^{h}$ & $141,8^{\mathrm{h}}$ \\
\hline 49 & $11 \times 15$ & NS-G- $11 \times$ RHA-N-49 & $0,780^{d}$ & $140,7^{\mathrm{h}}$ \\
\hline 49 & $11 \times 16$ & NS-G-11 $\times$ RUS-RF-OL-168 & $0,821^{d}$ & $135,8^{\mathrm{h}}$ \\
\hline 50 & $12 \times 14$ & NS-G-12 $\times$ RHA-R-PL-2/1 & $0,799^{h}$ & $140,6^{\mathrm{h}}$ \\
\hline 51 & $12 \times 15$ & NS-G-12 $\times$ RHA-N-49 & $0,800^{h}$ & $140,3^{\mathrm{h}}$ \\
\hline 52 & $12 \times 16$ & NS-G-12 $\times$ RUS-RF-OL-168 & $0,714^{i}$ & $135,8^{\mathrm{h}}$ \\
\hline 53 & $13 \times 14$ & NS-G-13 $\times$ RHA-R-PL-2/1 & $0,728^{\mathrm{h}}$ & $138,0^{\mathrm{h}}$ \\
\hline 54 & $13 \times 15$ & NS-G-13 $\times$ RHA-N-49 & $0,620^{i}$ & $140,9^{h}$ \\
\hline 55 & $13 \times 16$ & NS-G-13 $\times$ RUS-RF-OL-168 & $0,738^{p d+}$ & $131,6^{\mathrm{h}}$ \\
\hline \multicolumn{3}{|c|}{ LSD $_{0.05}$} & 0,014 & 2.17 \\
\hline \multicolumn{3}{|c|}{ LSD 01} & 0,022 & 3.26 \\
\hline
\end{tabular}

When breeding for desirable plant architecture, one of the most important parameters is the TLA, followed by $\mathrm{PH}$. That is why it is very important to be familiar with the mode of inheritance of this trait in the $\mathrm{F}_{1}$ generation. Analysis of the 
mode of inheritance for TLA per plant showed that there was an intermediate inheritance, partial dominance, dominance and super dominance of the better parent and for PH it was super dominance of the better parent (Table 1). Partial dominance as a mode of inheritance of the leaf area was determined by Cecconi and Baldini (1991) and Naik et al. (1999). The mode of inheritance of the leaf area was dominance of the better parent and superdominance was established by Kovačik and Škaloud (1990), Joksimović et al. (1997) and Hladni et al. (2003a).

Identification of inbred lines with high positive GCA values is of a great importance for the development of new productive sunflower hybrids (Hladni et al., $2008 \mathrm{~b})$. It is very difficult to combine all positive traits in one combination. The analysis of combining ability showed that the A lines and $R f$ testers differed significantly in GCA values (Table 2). Highly significant GCA values for both traits were demonstrated by cms A-line NS-G-7, NS-G-8, NS-G-9 and $R f$ tester line RHA-R-PL$2 / 1$. Lines with the best GCA for TLA per plant were chosen based on the GCA values (NS-G-7, NS-G-8) and PH (NS-G-9, NS-G-7). Line NS-G-10 has highly signifficant negative values of GCA for TLA per plant and PH and the wors general combiners (Table 2).

Table 2: GCA values for total leaf area per plant and plant height in sunflower inbreds

\begin{tabular}{|c|c|c|c|}
\hline \multirow{2}{*}{ No. } & \multirow{2}{*}{ Parents and hybrids } & \multicolumn{2}{|c|}{ GCA values } \\
\hline & & TLA & $\mathrm{PH}$ \\
\hline 1 & NS-G-1 & $0,011^{*}$ & $-8,60$ \\
\hline 2 & NS-G-2 & $-0,007$ & $-4,24$ \\
\hline 3 & NS-G-3 & $-0,043$ & $-5,35$ \\
\hline 4 & NS-G-4 & 0,022 & $9,62^{* *}$ \\
\hline 5 & NS-G-5 & $-0,132$ & $11,04^{\star *}$ \\
\hline 6 & NS-G-6 & $-0,018$ & 1,43 \\
\hline 7 & NS-G-7 & $0,220 * *$ & $13,65^{\star *}$ \\
\hline 8 & NS-G-8 & $0,197^{\star *}$ & $9,46 * \star$ \\
\hline 9 & NS-G-9 & $0,037^{\star *}$ & $16,79^{\star *}$ \\
\hline 10 & NS-G-10 & $-0,049$ & $-12,15$ \\
\hline 11 & NS-G-11 & $-0,056$ & $-9,49$ \\
\hline 12 & NS-G-12 & $-0,057$ & $-10,07$ \\
\hline 13 & NS-G-13 & $-0,125$ & $-12,10$ \\
\hline 14 & RHA-R-PL-2/1 & $0,021 * *$ & $1,00 * *$ \\
\hline 15 & RHA-N-49 & $-0,029$ & $4,12^{\star *}$ \\
\hline \multirow[t]{5}{*}{16} & RUS-RF-OL-168 & $0,008 * *$ & $-5,12$ \\
\hline & SE GCA/line & 0,004 & 0,63 \\
\hline & SE $\left(G_{C A}-G C A_{j}\right) /$ line & 0,006 & 0,89 \\
\hline & SE GCA/tester & 0,002 & 0,30 \\
\hline & SE $\left(G A_{i}-G C A_{j}\right) /$ tester & 0,003 & 0,43 \\
\hline \multirow[t]{2}{*}{$1-13$} & LSD $_{0.05}$ & 0,008 & 1,25 \\
\hline & LSD $_{0.01}$ & 0,012 & 1,88 \\
\hline \multirow[t]{2}{*}{$14-16$} & LSD $_{0.05}$ & 0,004 & 0,29 \\
\hline & LSD $_{0.01}$ & 0,006 & 0,44 \\
\hline
\end{tabular}


It is expected that the parental lines with higher mean values are better general combiners, and lines with lower mean values are worse general combiners, which was confirmed in this research. The inbred line with the best GCA for PH (NS-G-4) had the highest mean value for that trait, while the line with the worst GCA for PH (NS-G-13) had the lowest mean value for that trait. If the goal is the change of sunflower plant architecture, genotypes with the lower stem (NS-G-13, NS-G-11) and negative GCA are more desirable in breeding programs. The genetic distance between parental lines is a precondition for the expression of good specific combining abilities (SCA) Škorić et al. (2004).

Table 3: SCA values for total leaf area per plant and plant height in sunflower

\begin{tabular}{|c|c|c|c|c|}
\hline & & \multirow{2}{*}{$F_{1}$ hybrids } & \multicolumn{2}{|c|}{ SCA Values } \\
\hline & & & TLA & $\mathrm{PH}$ \\
\hline 1 & $1 \times 14$ & NS-G- $1 \times$ RHA-R-PL-2/1 & $0,089 * \star$ & $-1,75$ \\
\hline 2 & $1 \times 15$ & NS-G- $1 \times$ RHA-N-49 & $-0,044$ & $6,30 * *$ \\
\hline 3 & $1 \times 16$ & NS-G-1 × RUS-RF-OL-168 & $-0,046$ & $-4,55$ \\
\hline 4 & $2 \times 14$ & NS-G-2 $\times$ RHA-R-PL-2/1 & $0,040^{* *}$ & $-2,44$ \\
\hline 5 & $2 \times 15$ & NS-G-2 $\times$ RHA-N-49 & $0,019 *$ & $3,35^{\star *}$ \\
\hline 6 & $2 \times 16$ & NS-G-2 × RUS-RF-OL-168 & $-0,046$ & $-0,91$ \\
\hline 7 & $3 \times 14$ & NS-G-3 $\times$ RHA-R-PL-2/1 & $-0,023$ & $-1,41$ \\
\hline 8 & $3 \times 15$ & NS-G-3 $\times$ RHA-N-49 & $-0,044$ & 1,46 \\
\hline 9 & $3 \times 16$ & NS-G-3 × RUS-RF-OL-168 & $0,067^{* *}$ & $-0,05$ \\
\hline 10 & $4 \times 14$ & NS-G-4 $\times$ RHA-R-PL-2/1 & $0,039 * \star$ & $-1,14$ \\
\hline 11 & $4 \times 15$ & NS-G-4 $\times$ RHA-N-49 & $0,057 * *$ & $2,24^{*}$ \\
\hline 12 & $4 \times 16$ & NS-G-4 × RUS-RF-OL-168 & $-0,046$ & $-1,10$ \\
\hline 13 & $5 \times 14$ & NS-G-5 × RHA-R-PL-2/1 & $0,022^{\star}$ & $-0,72$ \\
\hline 14 & $5 \times 15$ & NS-G- $5 \times$ RHA-N-49 & $0,066^{\star *}$ & $-2,93$ \\
\hline 15 & $5 \times 16$ & NS-G-5 × RUS-RF-OL-168 & $-0,089$ & $3,65^{\star *}$ \\
\hline 16 & $6 \times 14$ & NS-G-6 $\times$ RHA-R-PL-2/1 & $-0,083$ & 0,06 \\
\hline 17 & $6 \times 15$ & NS-G-6 $\times$ RHA-N-49 & $-0,067$ & $3,02^{*}$ \\
\hline 18 & $6 \times 16$ & NS-G-6 × RUS-RF-OL-168 & $0,150 * \star$ & $-3,08$ \\
\hline 19 & $7 \times 14$ & NS-G-7 $\times$ RHA-R-PL-2/1 & $-0,038$ & $3,75^{\star \star}$ \\
\hline 20 & $7 \times 15$ & NS-G-7 $\times$ RHA-N-49 & $-0,061$ & $-7,29$ \\
\hline 21 & $7 \times 16$ & NS-G-7 × RUS-RF-OL-168 & $0,098 * \star$ & $3,53^{\star *}$ \\
\hline 22 & $8 \times 14$ & NS-G-8 $\times$ RHA-R-PL-2/1 & $0,031 * \star$ & $3,53^{\star *}$ \\
\hline 23 & $8 \times 15$ & NS-G-8 $\times$ RHA-N-49 & 0,001 & $-2,59$ \\
\hline 24 & $8 \times 16$ & NS-G-8 × RUS-RF-OL-168 & $-0,030$ & $2,23^{*}$ \\
\hline 25 & $9 \times 14$ & NS-G-9 × RHA-R-PL-2/1 & $-0,040$ & $2,78^{*}$ \\
\hline 26 & $9 \times 15$ & NS-G-9 $\times$ RHA-N-49 & 0,007 & $-1,59$ \\
\hline 27 & $9 \times 16$ & NS-G-9 × RUS-RF-OL-168 & $0,033^{* *}$ & $-1,19$ \\
\hline 28 & $10 \times 14$ & NS-G-10 $\times$ RHA-R-PL-2/1 & 0,014 & $-1,78$ \\
\hline 29 & $10 \times 15$ & NS-G-10 × RHA-N-49 & $0,035^{\star *}$ & $3,69 *$ \\
\hline 30 & $10 \times 16$ & NS-G-10 × RUS-RF-OL-168 & $-0,049$ & $-1,91$ \\
\hline 31 & $11 \times 14$ & NS-G-11 $\times$ RHA-R-PL-2/1 & $-0,076$ & 1,39 \\
\hline
\end{tabular}


Table 3: SCA values for total leaf area per plant and plant height in sunflower

\begin{tabular}{|c|c|c|c|c|}
\hline 32 & $11 \times 15$ & NS-G-11 × RHA-N-49 & $0,028^{\star \star}$ & $-2,90$ \\
\hline 33 & $11 \times 16$ & NS-G-11 × RUS-RF-OL-168 & $0,048^{* *}$ & 1,51 \\
\hline 34 & $12 \times 14$ & NS-G-12 × RHA-R-PL-2/1 & $0,015^{\star}$ & 0,72 \\
\hline 35 & $12 \times 15$ & NS-G-12 × RHA-N-49 & $0,048^{* *}$ & $-2,73$ \\
\hline 36 & $12 \times 16$ & NS-G-12 × RUS-RF-OL-168 & $-0,063$ & 2,01 \\
\hline 37 & $13 \times 14$ & NS-G-13 $\times$ RHA-R-PL-2/1 & 0,010 & 0,17 \\
\hline 38 & $13 \times 15$ & NS-G-13 $\times$ RHA-N-49 & $-0,045$ & $-0,04$ \\
\hline 39 & $13 \times 16$ & NS-G-13 × RUS-RF-OL-168 & $0,035^{\star *}$ & $-0,13$ \\
\hline \multicolumn{3}{|c|}{ SE SCA } & 0,007 & 0,02 \\
\hline \multicolumn{3}{|c|}{$\mathrm{SE}\left(\mathrm{S}_{\mathrm{ij}}-\mathrm{S}_{\mathrm{ki}}\right)$} & 0,010 & 1,54 \\
\hline \multicolumn{3}{|c|}{$\operatorname{LSD}_{0.05}$} & 0,014 & 2,17 \\
\hline \multicolumn{3}{|c|}{ LSD $_{0.01}$} & 0,022 & 3,26 \\
\hline \multicolumn{3}{|c|}{ GCA } & 5,18 & 5,59 \\
\hline \multicolumn{3}{|c|}{ SCA } & 62,12 & 17,96 \\
\hline \multicolumn{3}{|c|}{ GCA/SCA } & 0,08 & 0,31 \\
\hline
\end{tabular}

The greatest highly significant positive SCA value was found in NS-G- $6 \times$ RUSRf-OL-168 for TLA per plant and in NS-G-6 $\times$ RHA-N-49 for PH (Table 3). A highly significant positive value for $\mathrm{PH}$ in the $\mathrm{F}_{1}$ generation was found in the combinations NS-GS-1 $\times$ RHA-N-49 which was obtained by crossing one parent with a low PH GCA to another one that has a highly positive GCA for this trait (Table 2). These results support those obtained by Škorić et al. (2000), who determined that crosses with a good PH SCA usually involve one parent with high and one with low GCA values.

In the inheritance of the TLA per plant the non-additive component of the genetic variance had a predominant role. Further confirmation was provided by the values of GCA/SCA in the $\mathrm{F}_{1}$ generation which were smaller than one for all traits. According to Kovačik and Škaloud (1990), Joksimović et al. (1997), Bhat et al. (2000), Hladni et al. (2003a) and Hladni et al. (2008c) the biggest importance in the inheritance of this trait is given to the non-additive component of the genetic variance. Additive gene effects on the leaf area size were established by Cecconi and Baldini (1991) and Naik et al. (1999).

The non-additive gene effect had greater influence on PH. That was confirmed by the relationship GCA/SCA in the $\mathrm{F}_{1}$ generation which is less than one (Table 3). A higher contribution of non-additive genetic variance has been reported by Škorić et al. (2000), Joksimović et al. (2000), Hladni et al. (2004a) and Parameswari et al. (2004) for the inheritance of PH. By contrast, Bhat et al. (2000), Shekar et al. (2000), Ashok et al. (2000), Hladni et al. (2005) and Marinković (2005) found the additive component to be more significant in the inheritance of PH. By studying the proportional contribution of inbred lines, testers and their crosses in the total variability breeders come to different results with the same trait. The differences in the conclusions of different authors mentioned in this work can be explained by the dif- 
ferences in the plant material used in their studies (Hladni, 2010). The female A lines had the highest contributions to the expression of TLA per plant $71.8 \%$ and PH 80.3\% (Table 4). According to Škorić et al. (2000) the mother lines had a significant proportion in the expression of the plant height (55.8\%). The proportion of $R f$ testers was more significant in the expression of the TLA $(69.4 \%)$ reported Joksimović (1992) and in the expression of $\mathrm{PH}$ (62.5\%) as was concluded by Joksimović et al. (2000).

Table 4: Average percentage contributions of the female lines, testers and their interactions to the expression of sunflower morphophysiological traits

\begin{tabular}{lcc}
\hline \multirow{2}{*}{ Average contribution } & TLA & PH \\
\cline { 2 - 3 } & $\%$ & $\%$ \\
\hline Female line & 71,77 & 80,29 \\
Tester line & 3,13 & 10,96 \\
Line $\times$ tester & 25,10 & 8,75 \\
\hline
\end{tabular}

Significant manifestation of heterosis for agronomically important traits is the main precondition for obtaining productive sunflower hybrids as reported by Škorić et al. (2006).

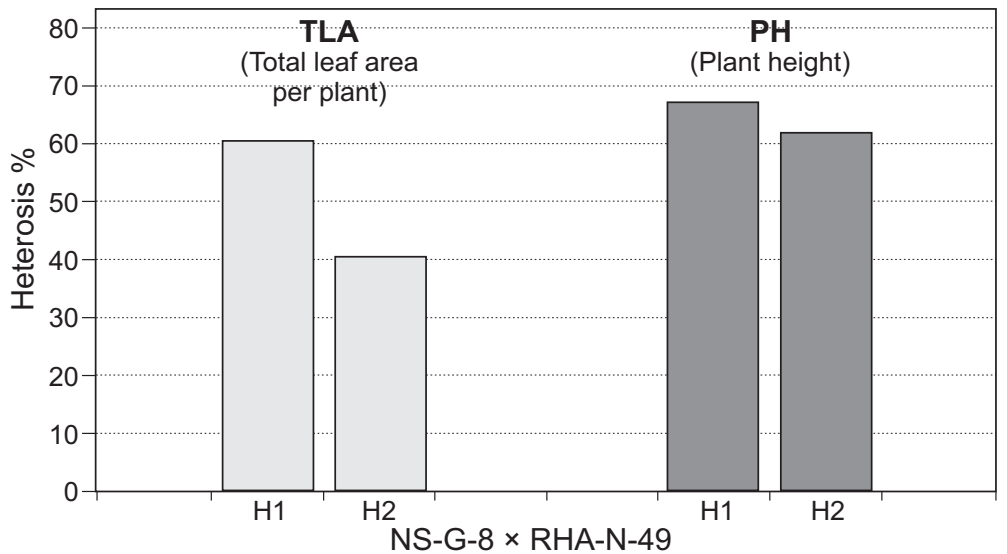

Figure 1: Heterosis for total leaf area (TLA) and plant height $(\mathrm{PH})$ relative to parental mean $\left(H_{1}\right)$ and better parent $\left(H_{2}\right)$

TLA total leaf area per plant; $P H$ plant height

Significant heterosis effect was found for both traits in relation to the parental average and in relation to the better parent (Table 5). Heterosis values relative to better parent differed significantly from those relative to parental average for all the traits. The determined effect of heterosis for TLA and PH compared to the parental average $(59.4 \%-93.3 \%$; $26.0 \%-75.05 \%)$, a in relation to the better parent $(39.8 \%$ $70.5 \% ; 13.8 \%-69.0 \%)$, Table 5. Significant heterotic effect on $\mathrm{PH}$ in relation to the parental average (19.0\%-66.0\%) and in relation to the better parent (6.1\%-51.6\%) with hybrid combinations was determined by Hladni et al. (2005). Positive and highly significant heterotic effect in relation to the better parent for $\mathrm{PH}$ announced 
Table 5: Heterosis for total leaf area (TLA) and plant height $(\mathrm{PH})$ relative to parental mean $\left(\mathrm{H}_{1}\right)$ and better parent $\left(\mathrm{H}_{2}\right)$

\begin{tabular}{|c|c|c|c|c|c|}
\hline & F hybride & & & & \\
\hline & 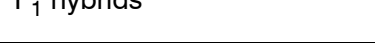 & $\mathrm{h}_{1}$ & $\mathrm{~h}_{2}$ & $\mathrm{~h}_{1}$ & $\mathrm{~h}_{2}$ \\
\hline $1 \times 14$ & NS-G-1 $\times$ RHA-R-PL-2/1 & 60,6 & 56,8 & 33,2 ** & 20,2 ** \\
\hline $1 \times 15$ & NS-G- $1 \times$ RHA-N-49 & 18,6 & 7,3 & 56,2 ** & 51,5 * \\
\hline $1 \times 16$ & NS-G-1 $\times$ RUS-RF-OL-168 & 24,0 & 12,2 & 26,0 ** & 14,6 ** \\
\hline $2 \times 14$ & NS-G-2 $\times$ RHA-R-PL-2/1 & 41,0 & 36,7 & 33,2 ** & 23,4 ** \\
\hline $2 \times 15$ & NS-G-2 $\times$ RHA-N-49 & 19,3 & 13,6 & 53,3 ** & $52,9 * \star$ \\
\hline $2 \times 16$ & NS-G-2 × RUS-RF-OL-168 & 6,6 & $-3,6$ & 30,2 ** & 21,6 ** \\
\hline $3 \times 8$ & NS-G-3 $\times$ RHA-R-PL-2/1 & 21,1 & 14,1 & 29,9 ** & $23,3 * \star$ \\
\hline $3 \times 9$ & NS-G-3 $\times$ RHA-N-49 & 1,7 & $-0,3$ & $46,3^{* *}$ & 42,9 ** \\
\hline $3 \times 10$ & NS-G-3 $\times$ RUS-RF-OL-168 & 16,0 & 7,7 & $26,7^{* *}$ & $21,4 * \star$ \\
\hline $4 \times 14$ & NS-G-4 $\times$ RHA-R-PL-2/1 & 40,1 & 31,2 & 36,3 ** & $36,1 * *$ \\
\hline $4 \times 15$ & NS-G-4 $\times$ RHA-N-49 & 24,9 & 23,2 & 52,7 ** & 41,6 ** \\
\hline $4 \times 16$ & NS-G-4 $\times$ RUS-RF-OL-168 & 1,9 & $-4,7$ & 32,2 ** & 30,8 ** \\
\hline $5 \times 14$ & NS-G-5 $\times$ RHA-R-PL-2/1 & 16,8 & 12,2 & 39,2 ** & 38,0 ** \\
\hline $5 \times 15$ & NS-G-5 $\times$ RHA-N-49 & 6,9 & 2,7 & 50,8 ** & $41,1 * \star$ \\
\hline $5 \times 16$ & NS-G-5 $\times$ RUS-RF-OL-168 & $-15,8$ & $-23,2$ & 38,9 ** & $38,8 * *$ \\
\hline $6 \times 14$ & NS-G-6 $\times$ RHA-R-PL-2/1 & 20,7 & 18,3 & 34,1 ** & 30,4 ** \\
\hline $6 \times 15$ & NS-G-6 $\times$ RHA-N-49 & 6,1 & 0,0 & 50,5 ** & 43,5 ** \\
\hline $6 \times 16$ & NS-G-6 $\times$ RUS-RF-OL-168 & 35,6 & 21,5 & 27,1 ** & 24,7 ** \\
\hline $7 \times 14$ & NS-G-7 $\times$ RHA-R-PL-2/1 & 89,5 & $70,5^{* *}$ & 46,8 ** & 44,1 ** \\
\hline $7 \times 15$ & NS-G-7 $\times$ RHA-N-49 & 76,1 * & 34,6 & 39,9 ** & $42,5^{\star *}$ \\
\hline $7 \times 16$ & NS-G-7 $\times$ RUS-RF-OL-168 & $93,3^{* *}$ & 45,1 & 52,3 ** & 41,2 * \\
\hline $8 \times 14$ & NS-G-8 $\times$ RHA-R-PL-2/1 & 88,6 * & 78,1 & 52,8 ** & 37,6 ** \\
\hline $8 \times 15$ & NS-G-8 $\times$ RHA-N-49 & 59,4 ** & 39,8 ** & 66,1 ** & $60,7 * \star$ \\
\hline $8 \times 16$ & NS-G-8 $\times$ RUS-RF-OL-168 & 50,3 & 25,9 & 50,2 ** & $36,4^{* *}$ \\
\hline $9 \times 14$ & NS-G-9 $\times$ RHA-R-PL-2/1 & 35,5 & 31,6 & 62,4 ** & 46,0 ** \\
\hline $9 \times 15$ & NS-G-9 $\times$ RHA-N-49 & 24,4 & 18,3 & 75,0 ** & 69,0 ** \\
\hline $9 \times 16$ & NS-G-9 $\times$ RUS-RF-OL-168 & 25,8 & 13,7 & 54,2 ** & 39,8 ** \\
\hline $10 \times 14$ & NS-G-10 $\times$ RHA-R-PL-2/1 & 44,7 & 34,2 & 39,2 ** & 17,2 ** \\
\hline $10 \times 15$ & NS-G-10 $\times$ RHA-N-49 & 27,4 & 10,0 & 61,7 ** & $45,3 * \star$ \\
\hline $10 \times 16$ & NS-G-10 × RUS-RF-OL-168 & 12,0 & $-7,7$ & 34,2 ** & 13,8 ** \\
\hline $11 \times 14$ & NS-G-11 $\times$ RHA-R-PL-2/1 & 19,6 & 18,1 & 37,9 ** & 22,2 ** \\
\hline $11 \times 15$ & NS-G-11 $\times$ RHA-N-49 & 18,1 & 7,9 & 48,8 ** & 41,3 ** \\
\hline $11 \times 16$ & NS-G-11 $\times$ RUS-RF-OL-168 & 19,2 & 3,7 & 33,4 ** & 19,2 ** \\
\hline $12 \times 14$ & NS-G-12 $\times$ RHA-R-PL-2/1 & 31,7 & 30,2 & $36,4^{\text {** }}$ & 21,1 ** \\
\hline $12 \times 15$ & NS-G-12 $\times$ RHA-N-49 & 18,6 & 10,8 & 47,9 ** & 40,9 ** \\
\hline $12 \times 16$ & NS-G-12 $\times$ RUS-RF-OL-168 & 0,9 & $-10,4$ & 33,0 ** & 19,1 ** \\
\hline $13 \times 14$ & NS-G-13 $\times$ RHA-R-PL-2/1 & 37,3 & 20,8 & $45,9 * *$ & $18,9 * \star$ \\
\hline $13 \times 15$ & NS-G-13 $\times$ RHA-N-49 & 6,8 & $-12,1$ & 63,2 ** & $41,6 * \star$ \\
\hline $13 \times 16$ & NS-G-13 $\times$ RUS-RF-OL-168 & 18,4 & $-6,6$ & 40,6 ** & 15,4 ** \\
\hline
\end{tabular}


Marinković et al. (2002) 84,2\%, while Hladni et al. (2003) had determined heterotic effect that was around $-7.4 \%$ to $-34 \%$ in comparison to the better parent. In combination NS-G-8 $\times$ RHA-N-49 heterosis values for TLA and PH were positive and highly significant in comparison to parental average $(59.4 \% ; 56.1 \%$ ) as well as better parent (39.8\%; 60.7\%), Figure 1.

On the basis of research of heterotic effect, it can be concluded that the effect of heterosis is not the same for all examined traits. High heterosis values can be expected in crosses of extremely divergent lines i.e., that heterosis is mostly a product of the difference in gene frequency between the lines that are being crossed.

\section{CONCLUSION}

Based on the examination of modes of inheritance and combining abilities of the selected inbred lines and $\mathrm{F}_{1}$ sunflower hybrids the following conclusions can be made:

The studied sunflower genotypes (inbred lines and hybrids) exhibited significant differences among the mean values of the studied total leaf area per plant and plant height. Highly significant positive values of GCA for both traits were found in inbred lines NS-G-7, NS-G-8, NS-G-9. The greatest highly significant positive SCA value was found in NS-G-6 $\times$ RUS-Rf-OL-168 for total leaf area per plant and in NS-G-6 $\times$ RHA-N-49 for plant height. The non-additive gene effect had greater influence for both traits. The female A lines had the highest contributions to the expression of total leaf area per plant and plant height $(71.8 \%, 80.3 \%)$, respectively. A significant heterosis effect was found for both traits in relation to the parental average and in relation to the better parent. In combination NS-G- $8 \times$ RHA-N-49 heterosis values for total leaf area per plant and plant height were positive and highly significant in comparison to parental average $(59.4 \%$; $66.1 \%)$ as well as to better parent (39.8\%; 60.7\%).

\section{REFERENCES}

Ashok, S., Mohamed Sheriff, N., Narayanan, S.L., 2000. Combining ability studies in sunflower (Helianthus annuus L.). Crop Res. (Hisar), 20(3): 457-462.

Bhat, J.S., Giriraj, K., Singh, R.D., 2000. Analysis of combining ability in sunflower. New Botanist 27(1/4): 37-43.

Burli, A.V., Pawar, B.B., Jadhav, M.G., 2001. Combining ability studies of some male sterile lines and restorers in sunflower. Journal of Maharashtra Agricultural Universities 26(25): 190-191.

Cecconi, F., Baldini, M., 1991. Genetic analysis of some physiological characters in relation to plant development of a sunflower (Helianthus annuus L.) diallel cross. Helia 14: 93-100.

Goksoy, A.T., Turan, Z.M., 2004. Combining abilities of certain characters and estimation of hybrids vigour in sunflower (Helianthus annuus L.). Acta Agronomica Hungarica 52(4): 361-368.

Hladni, N., Škorić, D., Kraljević-Balalić, M., Jocić, S., Dušanić, N., 2011. Line $\times$ tester analysis for yield components in sunflower and their correlations with seed yield (Helianthus annuus L.). Genetika 43(2): 297-306. 
Hladni, N., Jocić, S., Miklič, V., Kraljević-Balalić, M., Škorić, D., 2008b. Gene effects and combining abilities of sunflower morphophysiological traits. Proc. $17^{\text {th }}$ Inter. Sunf. Conf., Cordoba, Spain, 2: 545-550.

Hladni, N., Jocić, S., Miklič, V., Kraljević-Balalić, M., Škorić, D., 2008a. Combining ability for stem diameter and plant height in sunflower (Helianthus annuus L.). International Conference „Conventional and molecular breeding of field and vegetable crops“, Novi Sad, Serbia, 487-490.

Hladni, N., Škorić, D. and Kraljević-Balalić, M., 2008c. Line $\times$ tester analysis of morphophysiological traits and their correlations with seed yield and oil content in sunflower (Helianthus annuus L.). Genetika 40(2): 135-144.

Hladni, N., Jocić, S., Miklič, V., Mijić, A., Saftić-Panković, D., Škorić, D., 2010a. Effect of morphological and physiological traits on seed yield and oil content in sunflower. Helia 33(53): 101-115.

Hladni, N., Škorić, D., Kraljević-Balalić, M., 2003a. Genetic variance of sunflower yield components (Helianthus annuus L.). Genetika 35(1): 1-9.

Hladni, N., Škorić, D., Kraljević-Balalić, M., 2004a. Način nasleđivanja visine biljke i prečnika glave suncokreta (Helianthus annuus L.). Selekcija i semenarstvo X, 43-50.

Hladni, N., Škorić, D., Kraljević-Balalić, M., 2005. Heterosis for seed yield and components in sunflower. Genetika 37(3): 253-260.

Hladni, N., Škorić, D., Kraljević-Balalić, M., 2003b. Efekat heterozisa za komponente prinosa suncokreta (Helianthus annuus L.). Zbornik radova sa 44. Savetovanja industrije ulja, Budva, 35-41.

Hladni, N., Škorić, D., Kraljević-Balalić, M., Jocić, S., 2004b. Line $\times$ tester analysis for plant height and head diameter in sunflower (Helianthus annuus L.). Proc. $16^{\text {th }}$ Inter. Sunf. Conf., Fargo, North Dakota, USA, II, 497-502.

Hladni, N., 2010b. Genes and Sunflower Yield. Monograph. Foundation Andrejević, Beograd, Institute of Field and Vegetable Crops, Novi Sad, 116.

Jinks, J.L., 1983. Biometrical genetic of heterosis. Monograph on Theor. Appl. Genet. G. Heterosis, (ed.) by R. Frankel Springel -Verlag, Berlin, Heidelberg.

Joksimović, J., 1992. Ocena kombinirajućih sposobnosti kod nekih inbred linija suncokreta. Doktorska disertacija, Univerzitet u Novom Sadu, Poljoprivredni fakultet.

Joksimović, J., Atlagić, J., Škorić, D., 2000. Gene effect and combining ability for plant stature and harvest index in sunflower. Proc. of $15^{\text {th }}$ Inter. Sunf. Conf., Touluse, France, 47-52.

Joksimović, J., Marinković, R., Mihaljčević, M., 1997. Uticaj lisne površine na prinos semena i ulja kod $F_{1}$ hibrida suncokreta (Helianthus annuus L.). Proizvodnja i prerada uljarica 38: 509-516.

Kovačik, A., Škaloud, V., 1990. Results of inheritance evaluation of agronomically important traits in sunflower. Helia 13: 41-46.

Kraljević-Balalić, M., Petrović, S., Vapa, Lj., 1991. Genetika-teoretske osnove sa zadacima. Poljoprivredni fakultet, Novi Sad.

Marinković, R., 2005. Primena analize linija $\times$ tester u oceni kombinacionih sposobnosti. Zbornik radova Naučnog instituta za ratarstvo i povrtarstvo 41: 87-101.

Marinković, R., Škorić, D., Dozet, B., Jovanović, D., 2000. Line tester analysis of the combining ability in sunflower (Helianthus annuus L.). Proc. $15^{\text {th }}$ Inter. Sunf. Conf., Touluse, France, 30-35.

Naik, V.R., Hiremath, S.R., Giriraj, K., 1999. Gene action in sunflower. Karnataka Journal of Agricultural Sciences 12: 43-47.

Panković, D., Sakač, Z., Plesničar, M., Ćupina, T., Škorić, D., 1991. Leaf expansion and photosynthesis during growth and development of NS sunflower hybrids and inbred lines. Helia 14: 55-62.

Parameswari, C., Muralidharan, V., Subbalakshmi, B., Manivannam, N., 2004. Genetic analysis yield and important traits in sunflower (Helianthus annuus L.). Hybrids J. Oilseeds Res. 21(1): 168-170.

Sakač, Z., Ćupina, T., Plesničar, M., Panković, D., 1997. Adaptacija listova u usevu suncokreta. Proizvodnja i prerada uljarica 38: 490-505.

Seiler, G.J., 2010. Utilization of wild Helianthus species in breeding for disease resistance. Proc. Int. Symp. "Sunflower Breeding on Resistance to Diseases", Rusia, 36-50.

Shekar, G.C., Jayaramegowda, H., Nehru, S.D., Halaswamy, B.H., Ashok, S., 2000. Combining ability of early maturing cms lines and restorers in sunflower. Mysore J. Agric. Sci. 34(4): 289-293. 
Singh, R.K., Choudhary, B.D., 1976. Biometrical Techniques in Genetics and Breeding. Int. Bioscience Publishers. Hisar, India.

Škorić, D., Jocić, S., Hladni, N., Vannozzi, G.P., 2007. An analysis of heterotic potential for agronomically important traits in sunflower (Helianthus annuus L.). Helia 30(46): 55-73.

Škorić, D., Jocić, S., Jovanović, D., Hladni, N., 2004. Global sunflower breeding achievements. XXXIX Znanstveni Skup hrvatskih agronoma sa međunarodnim sudjelovanjem, Agronomski fakultet Zagreb, 172-174.

Škorić, D., Jocić, S., Molnar, I., 2000. General (GCA) and specific (SCA) combining abilities in sunflower. Proc. of $15^{\text {th }}$ Inter. Sunf. Conf., Toulouse, France, 23-30.

Škorić, D., Jocić, S., Jovanović, D., Hladni, N., Marinković, R., Atlagić, J., Panković, D., Vasić, D., Miladinović, F., Gvozdenović, S., Terzić, S., Sakač, Z., 2006. Dostignuća u oplemenjvanju suncokreta. Zbornik radova Naučnog instituta za ratarsvo i povrtarstvo 42: 131171.

Terzić, S., Zorić, M., Miladinović, F., 2006. Phenotype variability and inheritance of plant height and branching in $\mathrm{F}_{1}$ generation of sunflower. Helia 29(44): 87-95. 
